\section{Elegant security: Concept, evidence and implications}

\section{Graham Farrell}

University of Leeds, UK

\section{Nick Tilley}

University College London, UK
European Journal of Criminology

(C) The Author(s) 2020

\section{(c) (i)}

Article reuse guidelines: sagepub.com/journals-permissions DOI: I0.I I77/| 477370820932 I 07 journals.sagepub.com/home/euc

\begin{abstract}
Some security devices can be ugly, inconvenient or an infringement on civil liberties. This means that security is a quality of life issue as well as one of crime prevention. Here we propose that, in addition to preventing crime and being cost effective, security should preferably be ethical and unobtrusive, aesthetically neutral or pleasing, and the easy-to-use or default option. We describe security with such characteristics as 'elegant'. We use two case studies to explore how, as many types of crime have declined in recent decades, there was an increase in elegant and a decrease in inelegant security. We suggest that the lifecycle of some security technologies sees them evolve from inelegant to elegant, that continual improvement is required to keep ahead of offender adaptations, and that inelegant security can fall into disuse even if it prevents crime. It is hoped that this conceptual contribution might inform discussions about the appropriate form and role of security.
\end{abstract}

\title{
Keywords
}

Elegant security, security, dapper, crime drop, security hypothesis, situational crime prevention

\section{Introduction}

The way we live and the way we experience life are partly shaped by our concerns with security. Our lives are suffused with routine and special security precautions in myriad ways. This means that security is not only about crime prevention but also a quality of life issue.

\section{Corresponding author:}

Graham Farrell, School of Law, University of Leeds, Liberty Building, Leeds, LS2 9JT, UK.

Email: g.farrell@leeds.ac.uk 
Consider the modern car. A suite of security measures automatically engages to address the risk of theft from, theft of, and criminal damage to the vehicle. Doubledeadlock doors are remotely engaged. The ignition, fuel pump and fuel tank are automatically disabled (the 'immobilizer'). Aerials, stereos and on-board computers are integrated, inaccessible or dispersed. Windows are tough, insignia are irremovable and wing mirrors fold automatically on parking. Theft of vehicles fell 87 percent and theft from vehicles 78 percent in England and Wales between 1993 and 2016 (ONS, 2016). Similar declines in vehicle crime have been identified across Europe and elsewhere (Aebi and Linde, 2010; Tseloni et al., 2010; Van Dijk et al., 2007). Joyriding is in effect extinct and professional theft has been cut by three-quarters. ${ }^{1}$ Research finds that vehicle security devices, particularly the electronic immobilizer, have been central to these declines in Australia (Farrell et al., 2011; Kriven and Zeirsch, 2007), Germany (Bässmann, 2011), the Netherlands (Van Ours and Vollaard, 2016), the United States (Fujita and Maxfield, 2012) and the United Kingdom (Farrell, Tseloni and Tilley, 2011). In addition, electronic vehicle immobilizers have been found to be effective in a systematic review (Brown, 2015).

Even if it reduces crime, security is sometimes criticized as ugly and intrusive, inconvenient or restricting liberty. Here, we propose that the best security not only prevents crime but is tailored to be unobtrusive, seamless and sufficiently embedded that its protective role goes largely unnoticed by users. It becomes sufficiently normalized that it is barely perceived as security. We outline the concept of 'elegant' security wherein security and liberty are complements rather than substitutes, acknowledging at the outset the influence of Norman (2002) on the design of everyday things and Ekblom $(2005,2017)$ on designing-out crime, as well as others discussed further herein. The empirical sections of this study comprise case studies of the major declines in car crime and household burglary over the last quarter-century. The evidence suggests that crime has declined coincident with increases in elegant, and decreases in inelegant, forms of security.

This progress in key areas of security is, we suggest, a far cry from notions of fortress society. Churchill (2016: 857 ) notes how critics of security have sometimes linked it 'to mounting fear of crime and the breakdown of established trust relations, and argued that increasing security provision tends paradoxically to exacerbate concerns about insecurity'. We discuss criticisms of security further below and conclude that, although some have partial validity, many are conceptually limited or over-stated. Hence we also propose that closer examination of the continuum between elegant and inelegant security should lead to a more nuanced understanding of the relevant issues.

The broader context of this study is that an avalanche of security has permeated all walks of life in recent decades and been linked to the crime drop in high-income countries (Clarke, 2015, 2016). This avalanche has flowed into all domains of public and private life, including transportation, leisure and entertainment facilities, sports stadia, business facilities, shops and other commercial establishments, schools and universities. Despite, or perhaps because of, this, the range of security developments that has emerged in recent decades is sufficiently large that it has yet to be properly documented.

Not only has the scope and coverage of security increased, but there is evidence that it is increasingly embedded. Computer and physical systems are better designed and managed against crime than they used to be. Anti-virus computer software and firewalls, 
although imperfect, are now the default option with seamless auto-updates - a far cry from add-on software and manual updates of only a few years ago. Cybersecurity for online transactions is increasingly seamless. Recent reductions in smartphone thefts are attributed to remote disabling and kill-switches (Behavioural Insights Team, 2014): it is just as easy to steal a phone handset but the average reward has declined - the removal of reward here being a most elegant means of discouraging crime.

'Security' is a broad term. Reflecting the use of the Crime Survey of England and Wales in this study, our primary empirical focus here is on the widespread everyday security devices for preventing car crime and household property crimes in England and Wales. However, the characteristics of elegant security that we describe are, we suggest, more widely applicable, and in passing we touch on airport security (and hence terrorism), secure design of consumer products (which are less attractive to thieves) and aspects of policing. Hence we suggest that, although our main concern here is with elegant security pertaining to security devices, the conceptualization of elegance applies to the broader areas of situational crime prevention, problem-oriented policing and designingout crime.

This study is structured as follows. The next section provides background to the study by reviewing some existing criticisms of security. The third section details the concept of elegant security and describes its characteristics. The fourth section applies the concept to evidence about the international crime drop. The final section offers a discussion of related issues and a conclusion. Overall, since we think it is fair to say that (a) security against crime is a tremendously important feature of everyday human life and (b) the crime drop is generally acknowledged to be one of the more important criminological phenomena of modern times, the significance of the present study lies in offering what we believe to be a new perspective on both.

\section{Critiques of security}

Different types of security have been criticized in various ways. It is certainly the case that some security devices and technologies can reduce liberty and freedom, and that some are unsightly and awkward. Security with such undesirable characteristics is here framed as 'inelegant' security, that is, as the antonym to elegant security. In addition, some security technologies may be prone to misuse, particularly in autocratic regimes where the regulatory checks and balances of democracy are less prevalent, and this would render such an application inelegant, but this is not the focus here.

Different types of security work via different mechanisms and inhibitors that fall within the broader framework of situational crime prevention (Clarke, 2018). A number of criticisms have been aimed at situational crime prevention across the half-century over which it has evolved, and for the most part they have been addressed. Readers unfamiliar with this area are referred to Felson and Clarke (1997), Wortley (2010) and Gill (2014) for introductions to key issues, and Table 1 reproduces the summary of a recent review of seven key criticisms of situational crime prevention and the rebuttals (Clarke and Bowers, 2017).

Although recognizing that opinion is likely to remain divided on some of the issues in Table 1, the remainder of this section addresses additional criticisms levelled more 
Table I. Seven misconceptions of situational crime prevention.

\begin{tabular}{|c|c|}
\hline Criticism & Rebuttal \\
\hline It is simplistic and atheoretical & $\begin{array}{l}\text { It is based on three crime opportunity theories: } \\
\text { routine activity, crime pattern and rational choice. It } \\
\text { also draws on social psychology. }\end{array}$ \\
\hline $\begin{array}{l}\text { It has not been shown to work; it } \\
\text { displaces crime and often makes } \\
\text { it worse }\end{array}$ & $\begin{array}{l}\text { Many dozens of case studies show that it can reduce } \\
\text { crime, usually with little displacement. }\end{array}$ \\
\hline $\begin{array}{l}\text { It diverts attention from the root } \\
\text { causes of crime }\end{array}$ & $\begin{array}{l}\text { It benefits society by achieving immediate reductions } \\
\text { in crime. }\end{array}$ \\
\hline $\begin{array}{l}\text { It is a conservative, managerial } \\
\text { approach to crime }\end{array}$ & $\begin{array}{l}\text { It promises no more than it can deliver. It requires } \\
\text { that solutions be economic and socially acceptable. }\end{array}$ \\
\hline $\begin{array}{l}\text { It promotes a selfish, exclusionary } \\
\text { society }\end{array}$ & $\begin{array}{l}\text { It provides as much protection to the poor as to the } \\
\text { rich. }\end{array}$ \\
\hline $\begin{array}{l}\text { It promotes Big Brother and } \\
\text { restricts personal freedom }\end{array}$ & $\begin{array}{l}\text { The democratic process protects society from these } \\
\text { dangers. People are willing to endure inconvenience } \\
\text { and small infringements of liberty when these protect } \\
\text { them from crime. }\end{array}$ \\
\hline It blames the victim & $\begin{array}{l}\text { It empowers victims by providing them with } \\
\text { information about crime risks and how to avoid them }\end{array}$ \\
\hline
\end{tabular}

Source: Clarke and Bowers (2017: 110).

specifically at security. The two main themes of these criticisms are that there is too much security and that it is a socially harmful adverse product of capitalism. As an example of the latter, one commentator suggests that,

To make a profit, the security industry must sell security. And to sell security, it must help generate insecurities. In so doing, it reiterates the central logic . . that citizens need to be afraid, and ... plays a key role in the fabrication of a much wider culture of insecurity. (Neocleous, 2005: 350)

This seems to us to deny the experiences of victims, ignoring the financial and psychological harms and other costs due to crime (see, for example, Brand and Price, 2000; Home Office, 2005). The criticism seems to suggest that only reassurance is needed to allay the fears of a gullible society that has been duped by the security industry. Hence it appears to be a conspiracy theory that seems to us to be based on unevidenced assertions that lack credibility.

A broader set of criticisms, captured in the notion that there is 'too much security', is evident in the work of Zedner (2003), who identifies 'six paradoxes of security':

1. 'security pursues risk reduction but presumes the persistence of crime';

2. 'the expansion of security has enlarged not diminished the penal state';

3. 'security promises reassurance but in fact increases anxiety';

4. 'security is posited as a universal good but presumes social exclusion';

5. 'security promises freedom but erodes civil liberties';

6. 'security is posited as a public good but its pursuit is inimical to the good society'. 
We use Zedner's work as an example from a highly cited critical security studies scholar, and to make the criticisms specific. 'In each case,' Zedner noted, 'I observe that the reality of security provision conflicts with that which is promised or purportedly pursued' (Zedner, 2003: 157-8). We contend, however, that each of the six assertions is open to doubt and we address them briefly in turn in the remainder of this section.

The notion that security 'presumes the persistence of crime' has two strands. The first is not dissimilar to Neocleous's addressed above - an unevidenced conspiracy theory suggesting that government and private security want crime to continue and specifically that, "[f]or governments whose political capital is so heavily invested in fighting the war against crime, victory would be a double-edged sword' (2005: 159). The extensive literature on the international crime drop, including reports from government-backed victimization surveys, seems to undermine this notion. The second strand of this 'persistence of crime' is a rehearsal of the myth that prevented crime will relocate. Displacement is one of the misconceptions identified in Table 1 and there is extensive theoretical and empirical evidence showing that prevented crime often does not relocate and that the opposite - that is, a diffusion of preventive benefits beyond the original intention - often occurs (Barr and Pease, 1990; Cornish and Clarke, 1987; Eck, 1993; Guerette and Bowers, 2009; Hesseling, 1994).

With respect to Zedner's second paradox - that security has expanded the 'penal state' - we suggest that, insofar as meaning can be given to that term, this occurs largely independently of security. Moreover, some security devices, for instance those fitted to cars, have almost certainly led to a reduction in the number of people, particularly young people, caught up in the penal system. The third proposed paradox is that security measures may increase anxiety. We suggest this varies considerably with the specifics and may be true for some but not all. Increased lighting, for example, seems both to reassure and to prevent crime (Painter and Farrington, 1997). With respect to the fourth paradox, we likewise suggest that some security measures may involve social exclusion, but many do not: examples are the widening of aisles in markets to reduce theft from shopping bags (Poyner and Webb, 1997), remote deactivation of stolen phones, computer security systems, but also most everyday security measures such as household or business locks and bolts, which exclude would-be offenders but do not produce 'social exclusion' in the way that term is typically understood. With respect to the fifth paradox, we find it difficult to see how some forms of security erode civil liberties. For example, fuel caps that are opened from inside a car would not seem to jeopardize anyone's civil liberties, but neither do Internet firewalls and phishing filters, watermarks on money, time-lock safes, glass office doors, plagiarism detection software, remote deactivation of stolen goods, or many others. There are complex trade-offs in some instances - see, for example, Viscusi and Zeckhauser (2003) for an informative discussion of how, such as when faced with anti-terrorism procedures at airports, we sometimes happily accept reduced liberties, and this was also one of the misconceptions outlined in Table 1. Zedner's proposed sixth paradox - that the pursuit of security is 'inimical to the good society' - is, we suggest, similarly weak. One attribute of a good society is, presumably, that people are able to go about their lives without fear of being molested or having their possessions stolen. Many security devices and practices contribute to reductions in the real risks faced by citizens and do so unobtrusively, producing a net social benefit - a concept we also return to later. 
Table 2. Characteristics of elegant security.

\begin{tabular}{ll}
\hline Default & It has the default condition of secure rather than insecure \\
Aesthetic & It is aesthetically neutral or pleasing \\
Powerful & It has a powerful preventive mechanism \\
Principled & It is principled in ethical terms, consistent with liberty and freedom in society \\
Effortless & It is effortless, taking little or no time and effort to engage \\
Rewarding & It is rewarding in cost-benefit terms \\
\hline
\end{tabular}

It also overlooks the possibility that security removes opportunities that provoke, prompt or precipitate crime (see, for example, Wortley, 2017).

More broadly, it is difficult to see how we can sensibly ask whether there is too much or too little security. Changes in everyday life create new crime threats and eliminate old ones, requiring that security adapt to change. The car and the Internet, for example, produced new behavioural patterns and new crime risks, for which security measures have been and are being devised. Some kind of moratorium on security development would prevent this, which would seem absurd. Further, as we outline below, the best forms of security are sufficiently integrated and unobtrusive that they go largely unobserved as part of everyday life.

Overall, therefore, although critics of security have on occasion been useful in highlighting the downsides of some aspects of security, we suggest that the arguments are often indiscriminate and over-stated. The present study proposes what we hope is a more nuanced approach. Instead of asking whether the development of security measures should be uncritically supported or whether they should be condemned as altogether undesirable, we ask: What makes for benign security and how might it be encouraged? The preferable characteristics of security that we identify are outlined next.

\section{Characteristics of elegant security}

This section describes what we take to be the main characteristics of elegant security. They are embodied in the acronym 'dapper' (Table 2), and they are described below in turn. The characteristics were identified by a qualitative iterative process that drew on the examples and case studies discussed here (Tilley et al., 2015). The quantitative evidence presented later examines broad trends in elegant and inelegant security and, although specific 'dapper' characteristics are discussed, we do not quantitatively gauge the validity of individual characteristics. Hence we suggest that the evidence offers general rather than specific support for the conceptual elements of this study. Should this lead to more specific empirical studies based on the 'dapper' concept, then an aim of the present study will have been achieved. We liken this process to the conceptual identification of the CRAVED (Concealable, Removable, Available, Valuable, Enjoyable and Disposable) characteristics of frequently stolen products (Clarke, 1999) that led to subsequent verification efforts (for example, Kurland et al., 2017; Sidebottom, 2013; Petrossian et al., 2015). 


\section{Default}

A preferred characteristic of elegant security is that it changes the default from insecure to secure. This means that its resting condition is secure, and it does not require action on the part of the owner, manager or beneficiary to achieve the secure status. Many years ago, robberies on buses were reduced when the money paid in fares became default secure through the introduction of secure boxes (Smith and Cornish, 2012). Another everyday example is doors that lock automatically on closing rather than requiring a key to be turned in the lock (though these are not always aesthetically pleasing - see below). Another is time-lock bank vaults, which remove the possibility of hold-ups during opening times when banks are most vulnerable. Some modern cars have 'default' security systems that engage after 30 seconds or a minute if the car is left unattended.

The 'default' characteristic is important because it reduces the possibility of human error. In health care, the risk to patients of improperly administered medication has been reduced through default systems that require a swipe card to a medicine cabinet to ensure that the right patient receives the right medicine, at the right time, in the right dosage, by the right route, thereby reducing the chances of potentially criminally negligent care by nurses (Cox, 2008). Such errors are common and often occur as omissions - produced by forgetfulness, oversight or corner-cutting - which can create tempting crime opportunities.

\section{Aesthetic}

The aesthetic aspects of security are central to the stereotype of a 'fortress society' that is popular among critics. The negative cues and the psychological fear that some crude - inelegant - types of security may induce are at least partly responsible for the suggestion that security works in opposition to liberty. Razor wire, glass shards atop a wall to stop climbers, thick bars and grilles on windows and doors, padlocks, add-on bolts, door chains, vehicle steering wheel clubs, braces or 'crook locks', overt alarm boxes, CCTV, and often their attendant publicity, may all instil fear of crime and an air of perpetual unease into everyday life.

In contrast, elegant security tends to be built in to product design so that it goes unnoticed. Ergonomic harmony is central. Perhaps the somewhat inelegant but still preferable end of the spectrum is when crude security is designed to be less overtly hideous. Hence there are some reasonable examples of window bars that take a floral design, for instances, which makes them less obviously nasty even though they are still overt (see Ekblom, 2017). Better still is the window with secure materials for its frame and surround, secure glass and locks that are designed to avoid any invitation to crime while portraying no obvious sign of security. Hence we suggest that the characteristic runs on a spectrum rather than comprising a binary distinction.

\section{Powerful}

Good-quality security activates a powerful preventive mechanism. This is the most critical component of elegant security, since without it there is no crime prevention. Yet it is 
not easy to develop generic and powerful preventive measures, and the best appear to emerge as the product of crime-specific incremental developments. Hence the most effective vehicle and household security devices, which are described later, have evolved over time as successors to clunkier and less effective earlier efforts.

Some security is not particularly powerful. The examples of weak security that are discussed below are vehicle window etching and bars and grilles on windows to dwellings. The best security tends to meet industry standards set by experts. It is subject to revision of standards as needed, particularly in response to offender adaptations that overcome or circumvent it. However, a powerful preventive mechanism alone does not comprise elegant security, because it may be less likely to be purchased than competing products, and more likely to remain unused or fall into disuse, if it is awkward, time consuming or otherwise unappealing: some forms of add-on vehicle mechanical immobilizers, such as the steering wheel brace, are discussed further below in this context. Hence we consider a powerful preventive mechanism to be a necessary but not a sufficient component of elegant security.

\section{Principled}

Elegant security is principled. It is ethically and morally justifiable. Principled is distinct from 'legal' because it is possible for something to be legal yet unprincipled: an example would be broken glass that is sometimes seen atop walls to stop persons climbing over into a residence or business premises. Principled is likewise distinct from aesthetic because it is conceivable to have one but not the other: an extreme example is a hidden trap that, by being hidden, could be aesthetically neutral but injurious or potentially lethal and hence unprincipled.

When it comes to security technologies that are potentially intrusive, such as electronic eavesdropping, the safeguards of democratic society are intended to protect against egregious abuse: most electronic eavesdropping by police requires independent judicial review and approval, for instance. Democracies impose principled legal constraints that make the operation of some security measures not just inelegant but also unlawful. Hence we note that it is the application of some security technologies that may be unprincipled rather than the technologies themselves. This means that to the extent to which some technologies afford abuse more than others then greater safeguards are required.

Equity is an important principle. The fear has been expressed that improved security for some implies reduced security for others if crime relocates. This was discussed with other critiques earlier, and the evidence shows that displacement is uncommon, limited and often benign if it occurs, and that a diffusion of preventive benefits is more likely. As with most consumer products, price may be an equity issue when some makes or models are expensive and better afforded by the affluent. But, as with most consumer products, the market grows for successful products and they become cheaper and more widely available, sometimes quite quickly. Thus, as Felson and Clarke (1995) noted, special add-on security measures become popular and routine over time. Further, the state can also be a security provider and arguably should prioritize those at most risk, such as people and places prone to repeat victimization (Ignatans and Pease, 2016). 
It has been suggested that the development of elegant security falls foul of principles relating to individual freedom of choice. Liberty is allegedly violated where new defaults are created, so to speak, behind the backs of those making decisions (see Grüne-Yanoff, 2012). Recent discussions of the use of facial recognition systems by police fall into this category (for a useful summary of both sides, see The Economist, 2019). More broadly, the debate over choice architecture is complex and the literature extensive, but suffice it to say here that defaults are ubiquitous and in our view mostly benign, providing options for agents to override them if preferred. Moreover, the previous state of affairs - that is, prior choice architecture - also imposed a default choice but was a situation in which crime risks had not been considered.

\section{Effortless}

Top-notch security tends to require little time or effort on the part of the user. Remote vehicle security systems, for example, require only that the owner press a single button on the key chain for full activation. Previously, each vehicle door lock had to be physically activated on an individual basis (typically, a knob would be pushed down), and an add-on steering wheel lock had to be separately engaged (entailing some awkward wrestling with the device). Such devices varied in nature, reflecting the stage of evolution. Intermediary steps to remote activation included, on occasion, a separate key used in the dashboard or elsewhere before leaving the vehicle.

There is some overlap between security that is effortless and that where it is the default, and in some instances they are coterminous. However, the two can be distinct. In some cars, for example, a level of security is automatically engaged when the vehicle is left unattended for a minute or so, but the highest level of security is engaged only by the user's remote activation. Likewise, in households, whereas doors and windows might be secure by default owing to their design, perhaps the highest level of security - involving deadlocks, sensors and security lights - needs to be pro-actively triggered. More importantly for present purposes, however, the characteristic of time and effort no longer being required seems a particularly pertinent benefit.

In airports, the passenger's journey to the plane itself is made arduous by contemporary security procedures that are intended to make flights safer. At the point of writing there is still a lot of time and effort on the part of travellers. They wait to pass through security, have to remove various items of clothing such as belts and shoes, and have to take laptops and liquids out of hand luggage, prior to X-rays of bags and persons. This is then followed, on occasion, by further searches. Some aspects of the process have become more elegant, such as e-passports, rapid security checks for pre-approved frequent travellers, and the introduction of biometric-based checks (including body scans and facial recognition systems), which, particularly if they improve with further development as seems likely, should prove speedier and more efficient than previous methods.

In the broader realms of crime prevention and policing, automatic licence plate recognition technology is a vast improvement on individual vehicle checks. It facilitates automated scans for a wide variety of issues relating to vehicle and owner, which previously took an immense amount of investigative time. Computerized cross-referencing leaves police officers to manage the large amount of information that not only facilitates 
road safety but is likely to reduce other crimes (see ACPO, 2004). Likewise, many traffic-calming measures are unobtrusive and trigger a psychological mechanism that causes drivers to slow down or to improve their driving, such as rumble strips that prompt the driver to remain within the carriageway and lines on the road that are increasingly close together, which cause a driver to reduce speed when approaching a junction (Moskvitch, 2014).

\section{Rewarding}

Elegant security is rewarding in cost-benefit terms. The net social cost of security includes not just manufacturing or purchase and running costs and the saved cost of prevented crime. It also includes the relevant psychological and other social cost elements, such as those relating to the other characteristics of elegant security that are identified here, as well as the net benefit from security of reduced carbon costs (Skudder et al., 2016).

Per unit monetary purchase costs of security fall over time. Most consumer products are initially expensive and purchased by a small proportion of the population, and this is true of household security devices. Economies of scale and competition increase availability and reduce per unit prices over time, making security more affordable and widely available. In turn, new security product developments are marketed at a higher price and go through a similar lifecycle. Hence, although in practice the calculation of net social benefit of security is difficult and a moving target, it is an important conceptual element of elegant security.

\section{Trends in security and crime: Two case studies}

This section presents two case studies that are intended to illustrate the extent, nature and importance of the concept of elegant security. The use of security devices relating to vehicles and households is examined. This allows us to build on existing research relating to the role of security in reducing vehicle crime and household burglary. The data source is the Crime Survey for England and Wales (CSEW), which, although imperfect, is generally accepted as being unrivalled in the manner in which it has measured trends in crime and security.

Since the early 1990s, vehicle theft and household burglary have declined dramatically in most developed countries. As discussed earlier, there is strong evidence that this was due to improved vehicle and household security. The CSEW finds that between their 1993 peaks and 2016, the vehicle-related theft rate fell by 83 percent and the domestic burglary rate by 76 percent (ONS, 2016). ${ }^{2}$

\section{Vehicle security}

Car theft takes different forms, including joyriding and theft for transportation (both forms of temporary theft, mostly by adolescents), and theft for resale of the vehicle or its parts (forms of permanent theft, typically by more experienced thieves). Temporary theft is now in effect extinct, and even permanent theft has experienced a major decline across the last quarter-century. 


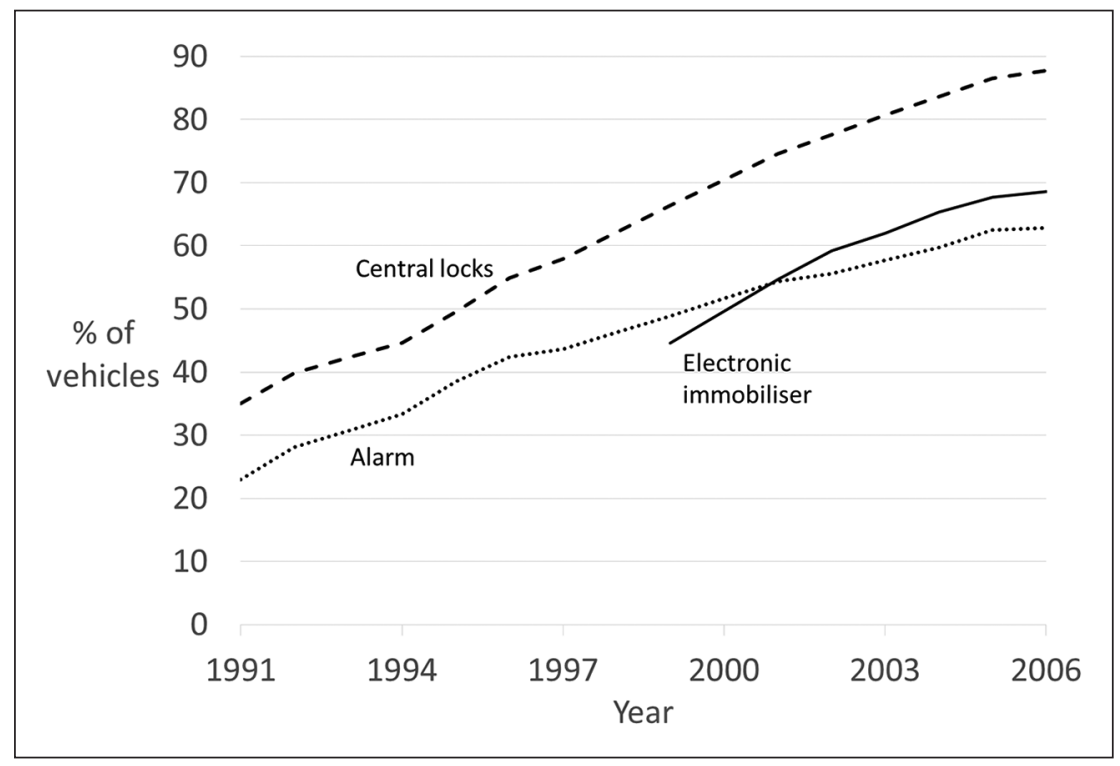

Figure I. Increasing vehicle security devices.

Elegant. A snapshot of vehicle security was given in the Introduction. The driver approaches the modern car and their keyless fob does the work remotely. It unlocks the double-lock doors and disables the electronic immobilizer that otherwise isolates the ignition, fuel pump and fuel tank. The movement alarm is deactivated but the tracking device remains hidden and in place as always. Audio equipment, part of which used to be a removable 'stereo' unit that was a frequent target of theft from vehicles, is now integrated and dispersed, along with satellite navigation systems. Likewise aerials, once an easy vandalism target because they were liable to be snapped or bent, are now integrated, small, robust or flexible. Wing mirrors, a similar vandalism attractor, now often automatically open and fold to reduce deliberate or even accidental damage. The toughened glass windows are difficult for thieves to break and, as the car moves off, the doors autolock to promote passenger safety and prevent unwanted entry. The security is part of a larger suite of safety measures, such that the satellite navigation warns if the speed limit is passed, reducing dangerous driving. On arrival at the destination, the car's parallel parking system reduces the risk of collision. When the driver leaves the vehicle, the layered suite of security automatically engages. User effort is minimal and security is unobtrusive, to the extent it goes unnoticed by the uninitiated: in our experience, current undergraduate students often do not realize that things were ever any different! The CSEW does not measure every device or design change, but trends in the use of significant security devices are shown as Figure 1.

Inelegant. How times have changed. Typical car security on an early 1980 s car consisted of individual door locks, plus, perhaps, a mechanical immobilizer and window etching. Individual push-button door locks took time, effort and a good memory to lock each door 


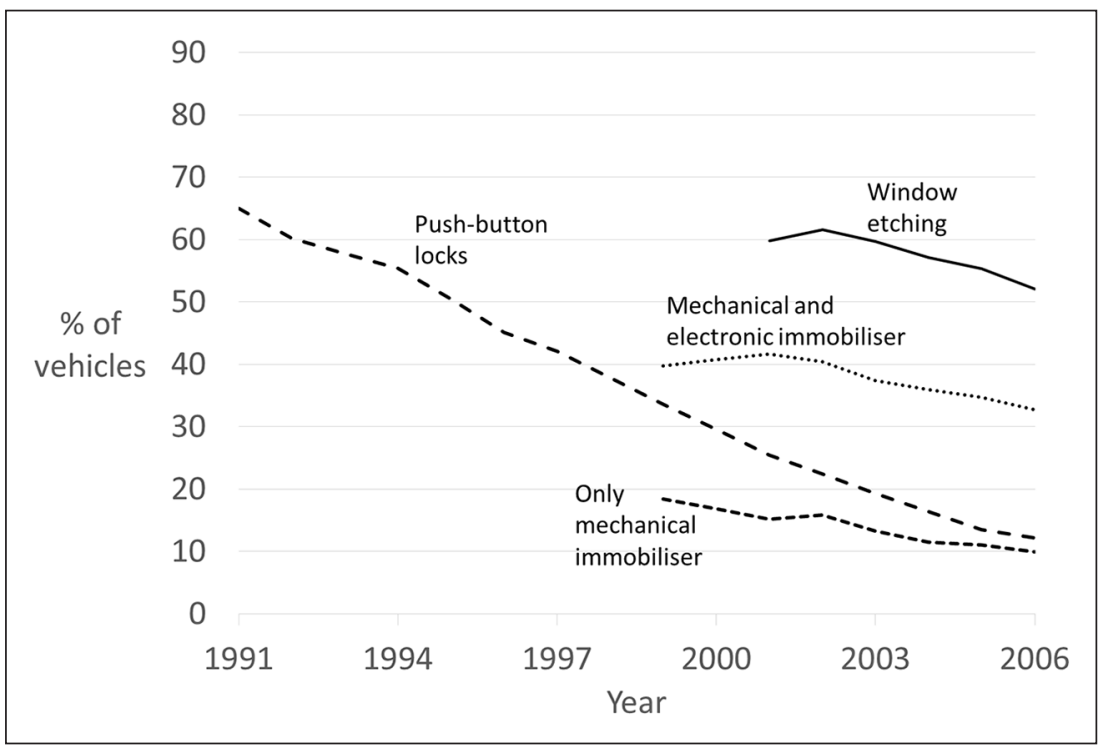

Figure 2. Decreasing vehicle security devices.

when leaving the car, and to open them for passengers on returning. People forgot or did not bother, but it mattered little because the locks were weak and easily overcome with a screwdriver or slim-jim tool (Light et al., 1993; Spencer, 1992). A 1988 study found that 'the ease with which locked cars can be broken into would be laughable if it weren't so serious. Our security tester has got into nearly all cars he has checked in a matter of seconds, using the unsophisticated tools of the car thief's trade' (Which? 1988: 118; cited in Clarke and Harris, 1992: 37). Though weak push-button door locks have not been measured by the CSEW, their maximum prevalence is the remainder when central locking is subtracted from the total. It is sufficient for present purposes to assume push-button locks declined inversely with the increase in central locking, shown in Figure 2 as pushbutton locks alongside other devices discussed here as being inelegant.

A mechanical immobilizer is a steering wheel brace (crook lock or club) or a hand/ emergency brake lock. It requires a separate purchase, transportation (often at the front passenger's feet), and a fiddly installation each time the vehicle is parked. Drivers forget or perhaps do not bother to fit them, particularly for stops that are brief or perceived as low risk, or when they are in a hurry. Mechanical devices are often high visibility (yellow or red in colour) to deter offenders, but as such are a physically unattractive visual cue of fortress society (see later discussion). However, mechanical immobilizers are fairly effective in reducing vehicle-related theft. This last point is crucial because we interpret the decline in mechanical immobilizers as attributable to their general inelegance - the time, effort and psychological cost involved - rather than their ineffectiveness. Their decline was undoubtedly accelerated by the spread of integrated electronic immobilizers, but the fact that mechanical immobilizers were superseded speaks to their inelegance. This evidence is consistent with our conceptualization of a powerful preventive mechanism as a necessary but not a sufficient condition for elegant security. 
Window etching is relatively cheap, is a permanent default option, is fairly innocuous and requires nothing further from the vehicle user. These reasons probably explain why it became so popular - it was a low-cost response to rising crime rates. Crucially, however, there is no evidence of its effectiveness. One study omitted window etching because "preliminary analysis suggested window etching conferred little additional security' (Farrell, Tseloni and Tilley, 2011: 26). The evidence fits with the theory because window etching's preventive mechanism is weak or absent: it does nothing to physically block entering or starting a vehicle (and hence nothing to deter theft from a vehicle); it embodies no deterrence against temporary theft (thieves will not care if windows are etched); the only detection threat it could confer is against permanent theft, but this is negligible (since windows are not the most valuable parts and are unlikely to be traced).

Note that mechanical immobilizers and window etching are inelegant for different reasons. Mechanical immobilizers have a somewhat powerful preventive mechanism, but they are not the default, not aesthetically pleasing and far from effortless. Hence, although 'preventive mechanism' is arguably a dominant characteristic among those discussed here, even an effective device can be unattractive and unused. In contrast, window etching, despite being the default, fairly aesthetically neutral, principled and effortless, simply does not work to prevent crime. This comparison supports the conceptualization of elegance in terms of a combination of characteristics.

\section{Household security}

There is good evidence that the spread of improved household security was responsible for the rapid decline in household burglary in England and Wales. However, the research underpinning that statement has not, to our knowledge, been replicated outside of England and Wales and so will be briefly summarized here. It has been found that the proportion of households without security decreased in the early 1990s from around 1 in 5 to less than 1 in 20 . The use of combinations of the more effective devices also increased rapidly at this time - the more prominent effective devices being door and window locks plus internal and external security lighting. The correlations between security developments and the pattern of falls in domestic burglary accord with theoretical expectation: the most telling empirical signature is that only forced entries to households declined. That is, burglaries involving breaking all or part of the door or window (frame, pane or lock) declined when security increased. In contrast, unforced entries did not decline where the burglar pushed past, used deception, had a key or found an unlocked door or window. These patterns are explained by more and better household security (Tseloni et al., 2017).

Elegant. Figure 3 shows trends in the prevalence of individual household security devices. The trends are broadly consistent with our thesis: there are increases in elegant devices and decreases in inelegant devices. External movement-activated lighting is elegant because it would often exist even if security were not a concern, plus it powers off as a cost-saving and environmentally friendly measure. Stronger door and window frames are elegant because for the most part they have the same physical form as 


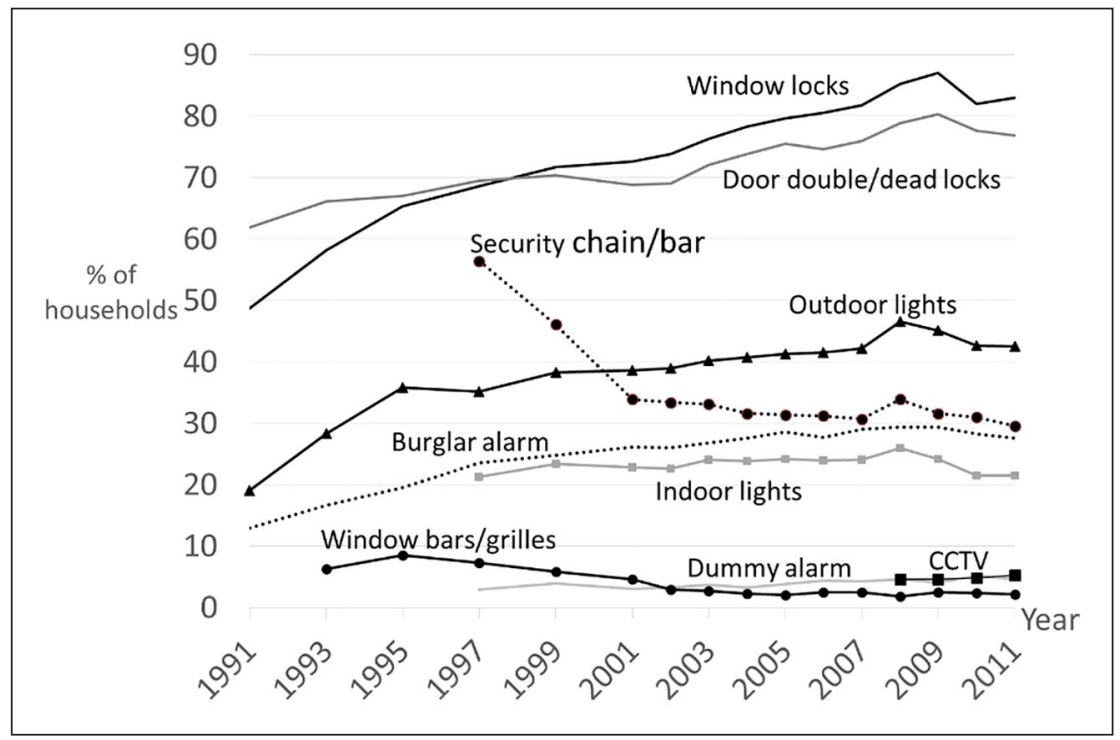

Figure 3. Household security devices.

previous frames, and toughened glass is visually identical but harder to break. Likewise, double-paned (double-glazed) windows and storm windows are elegant largely because they exist for insulation purposes and the difficulty created for burglars is a bonus (Tilley et al., 2015).

However, household security devices are not necessarily as elegant as we would wish. Locks have greater elegance when they are integrated than when they are retrofitted. Most integrated locks do not require the addition of a nut to a bolt as was common on earlier generations of add-on window locks. However, they may still require some element of time, effort and recall. Doors that contain a high-quality lock, such as the British Standard 5-lever mortice lock, avoid the need for the fitting of an add-on bolt inside the door. An integrated door lock is largely invisible to occupants (relative to add-on bolts) aside from the escutcheon. Hence, although the user still needs to lock the door each time, and they may forget, many modern integrated locks are a big improvement on what went before but remain only partially elegant; they deserve to be superseded by further improvements.

Inelegant. Two sets of inelegant household security are examined here. They are 'security bars and chains' and 'window bars and grilles'. Security bars and chains are often highly visually intrusive, though some more than others, and they embody fortress society cues. They impose a time and cost upon the user on each occasion they are used. A security bar across a door, for example, needs to be put in place each time. A security chain is also socially awkward because it allows the door to be opened only a crack to greet new visitors. Door chains are unsightly, awkward and easy to forget, they fall into disuse, and they are seldom particularly robust. 
Although burglary has declined from the mid-1990s, these inelegant security measures were either in steep decline, or never particularly popular, or both (Figure 3). Security chains and bars had been popular but their prevalence declined heavily in the second half of the 1990s - halving over the decade from the mid-1990s. The prevalence of window bars and grilles declined by three-quarters from a 1995 peak of 8.5 percent of households to 2.9 percent by 2002 and 2.2 percent by 2011. It is debatable whether dummy alarms or household security CCTVs are inelegant or not, but the main point here is that they were never popular and so cannot have played a role in burglary's decline. What we conclude is that the least elegant forms of household security are not responsible for the decline in crime, and we conjecture that this is contrary to popular perception.

\section{Discussion}

This section teases out further issues.

\section{The lifecycle of security}

The history of security is of its gradual evolution. Newman (2004) examines how vehicle security developed alongside vehicle safety over the last century. A study of the history of lock-picking wryly observes how:

By 1851, both the Chubb and Bramah locks had long been considered permanently unpickable. As far as any distinct view prevailed, security-product development was conceived in terms of a stadial progression, which advanced from primitive methods of construction, through warded locks, to the telos of the 'unpickable' locks of the nineteenth century. (Churchill, 2015: 67)

With Churchill's lessons from the 1850s in mind, note that we are not proposing that elegant security is unassailable. Rather, it evolves in stages, will benefit from continual improvement and may well, at some stage, be overcome.

To contain a surging crime form, the first response is typically an inelegant retrofit as a quick and short-term response. This is followed by improved designs and new solutions. Several generations of design are usually required until it begins to approach elegance. And this iterative design process can occur in parallel with adaptive responses by offenders: recent experience with immobilizer by-passing follows this co-evolutionary process (Brown, 2016; Ekblom, 1999; Menon, 2016). Perhaps the process is better conceived as a security lifecycle: when a once-elegant form of security is overcome, it needs to be replaced by a new generation that regains effectiveness while retaining elegance.

\section{Smart security}

Smart locks and other smart security, integrated with the Internet of things, is generating a new wave of potentially elegant security. One review notes about household smart locks: 
[They] let you receive alerts and track who's entering and leaving your abode; email limitedaccess digital 'keys' to visitors, children, trusted service workers or guests when you're not home; and remotely lock and unlock when you're away from home. . . you could program a night mode action that locks the doors and also turns off the lights and closes the shades. If a friend, family member or service worker rings your smart doorbell while you're away, you can visually confirm who it is via the smart doorbell, then remotely unlock the door to let them in.

(Wolpin, 2016)

Remote, Internet-based and proximity-activated security of different types offer great potential and convenience. Much modern vehicle security is somewhat smart already, using proximity sensors to activate or disarm it. The trend towards smartphone apps that control and monitor security (and other technologies) is likely to continue. In households, automatic locking of doors and windows on departure, alongside remote security checks, including video (of callers at the door), offers the prospect of better and more elegant security with few of the negative aspects. However, manufacturers need to beware of interception, breach and hacking (Thomson, 2016); a powerful preventive mechanism is a prerequisite. These problems are typically amenable to situational prevention (see, for example, Koumpis et al., 2007, on social engineering).

\section{Consideration of net social benefit}

This study speaks to quality of life and, therefore, to a concern to maximize net social benefit. In traditional cost-benefit analysis, tangible and intangible (including psychological) costs and benefits would be monetized. Assessment of change over time would need estimates of perceptions of cost and how these change. Three decades ago, mechanical immobilizers were deemed desirable and were used by many vehicle owners - the preventive benefit was taken to outweigh their negative aspects. Over time, however, vehicle owners changed their mind and the prevalence of mechanical immobilizers declined. This suggests that owners' perceptions changed relative to those of other security options. Hence, although elegant security is theoretically compatible with cost-benefit and cost-effectiveness analysis, quantification of its elements is tricky and extends beyond the scope of the present study.

\section{Politics and philosophy}

We suggest that elegant security squares with the philosophy of liberal paternalism embodied in nudging (Thaler and Sunstein, 2008) that has been proposed for situational crime prevention more generally (Pease and Laycock, 2012). Through elegant choice architecture, security and liberty can be envisaged as complements rather than substitutes. In particular, the 'default' characteristic of elegant security comes straight from the choice architecture literature. The actors of central interest are potential victims who are empowered by 'principled' security. Principled security involves, quite rightly, less choice for potential offenders but at the same time it avoids cruel or unusual punishment - and, in the best case, no crime opportunity is afforded. 


\section{Elegant situational prevention}

The focus here has been security devices. These trigger mechanisms that, as noted earlier, sit within the situational crime prevention repertoire. We think that the concept of elegance might apply more generally and that elegant situational prevention might be an appropriate term.

\section{The secure invisible hand}

It was not the benevolence of security manufacturers that led them to develop socially elegant solutions to crime. Rather, the invisible hand of the market produced a broader diffusion of social benefit. Like all consumer goods, the spread of expensive new security products can be uneven until economies of scale and competition reduce per unit prices over time. Our impression of security effects, however, is that there has been a broad if gradual permeation and benefit across social strata, and that variation may lie mainly in the rate of spread of increased safety. This pattern seems to be common to most socioeconomic progress, and where any inequity is deemed excessive then policy tools to address it could be appropriate (Ignatans and Pease, 2016).

\section{The waning of fortress society?}

In discussing the 'principled' component of elegant security above, we noted the need for democratic society to maintain safeguards against abusive applications of security technologies. Where safeguards fail they must be redoubled. With respect to the conventional crimes that are our main focus here, however, the evidence suggests the international crime drop has coincided with an increase in elegant security solutions and a decline in inelegant security solutions. This does not square with notions that improved security entails the creation of a fortress society comprising either ugly edifices and/or cosy enclaves from which the poor are excluded, even though such developments may sometimes be found (Davis, 1990). And is it quite contrary to the view expressed by some of security's more dismissive critics.

The notion of fortress society is that of an extreme form of inelegant security that detrimentally affects quality of life. Its pessimism was fostered by the high crime rates of the 1980s, when crime appeared to be increasing relentlessly. Such fears are sometimes predicated on a stereotype of security, or situational crime prevention (SCP) more generally, as exclusionary or invasive target hardening. And, although some applications of target hardening can be elegant, it is but one of the 25 techniques of SCP (Clarke, 2012, 2018), most of which are not so easily misrepresented. And, simply put, where target hardening is excessively exclusionary or invasive it would be considered inappropriately inelegant.

\section{Elegant security: A crime prevention panacea?}

We have received some objections to the arguments advanced so far. Let us briefly address them. The first is that elegant security may not be relevant to serious offences 
such as 'organized crime', 'the drug industry' and 'cybercrime'. We just do not know, but we suspect that there may be elegant security measures against specific offences under these broad categories. Take romance scams as one form of cybercrime as an example. We can see nothing inelegant about designing user-friendly websites that make it difficult for fraudsters to post multiple personae to entice the vulnerable into exploitative relationships. Organized car theft has been significantly reduced by improved vehicle security. In relation to specific crimes associated with the drug industry, the development of tamper-proof packaging was quite an elegant way of forestalling mass murder through adding poison pills to pots of painkillers. All this means that the limits to elegant security have yet to be found. That there may be limits is no reason to claim that elegance is not a desideratum. Where inelegant security measures are deemed admissible, even if there is a real trade-of between security and some other social value, what we would argue is that a desirable direction of travel is towards greater elegance. For example, we do not think Tasers are a particularly elegant aspect of policing but, when used appropriately, they are less lethal and therefore more principled than firearms and more powerful than batons.

The second objection is that there are security measures that are inelegant. Quite so! That is why we have written this article. But the fact that some are inelegant does not mean that all are. The inelegance suggests a need to move towards elegance. And there are signs that greater elegance is possible.

The third objection is that some inelegant security measures may still be publicly acceptable. Again, quite so! This is why we made 'principled' a key part of elegance. Principle is, of course, rather different from popularity, and in particular cases there is scope for legitimate debate.

We have not argued that all effective crime prevention measures are elegant. Those that are not should, we propose, seek improved designs or alternatives that are more elegant. In some cases, it may be reasonable to allow efficacy to trump other aspects of elegance. As we write this, the response to Covid-19 brings these kinds of trade-off into rather sharp relief. The normal freedoms of action and assembly, which most of us cherish, have been restricted on utilitarian grounds. Most of us also accept that in, this instance, pragmatism takes precedence.

\section{Conclusion}

This study has outlined and explored the characteristics of a concept of elegant security. The main conclusion, or perhaps an aspiration, is that the unpacking of security's characteristics should be a step towards a nuanced discussion of the role and nature of security in society. Four further conclusions derive from the discussion of theory and evidence as follows:

- Security that is only good at preventing crime but inelegant in other respects is likely to fall into disuse as more elegant solutions are identified.

- The decline in many crime types in high-income countries has been concurrent with an increase in elegant, and a decrease in inelegant, security. 
- Crude stereotypes of security as synonymous with a dystopian fortress society are unhelpful.

- The best security is that which is not only efficient at preventing crime but convenient, unobtrusive and ethical.

All this said, we remain far from a world without crime or one where universally elegant security ensures physical and psychological wellbeing. Some types of crime have increased in recent years, particularly those facilitated by the Internet and other telecommunications advances. It is hoped, however, that the present study advances a conceptual framework within which discussions of the appropriate role for security might be fruitfully developed.

\section{Acknowledgements}

We are indebted to David Churchill and to anonymous reviewers for comments on earlier drafts.

\section{Funding}

The author(s) disclosed receipt of the following financial support for the research, authorship, and/ or publication of this article: The authors acknowledge the contribution of grants RES-000-222386, ES/K003771/1, ES/K003771/2 and ES/L014971/1 from the Economic and Social Research Council.

\section{ORCID iD}

Graham Farrell (iD https://orcid.org/0000-0002-3987-8457

\section{Notes}

1. Recent upticks in high-end car theft using immobilizer by-pass technologies or hacking of on-board diagnostics ports - discussed further herein - will require further iterations of design improvement by some manufacturers (Brown, 2016; Menon, 2016; Tobin, 2014).

2. Rates per 1000 households, calculated from Table A2 of ONS data at http://www.ons.gov.uk/ peoplepopulationandcommunity/crimeandjustice/datasets/crimeinenglandandwalesappendixtables (accessed 2 August 2016).

\section{References}

ACPO (Association of Chief Police Officers) (2004) Driving Crime Down: Denying Criminals the Use of the Road. London: ACPO.

Aebi MF and Linde A (2010) Is there a crime drop in Western Europe? European Journal on Criminal Policy Research 16: 251-277.

Barr R and Pease K (1990) Crime placement, displacement and deflection. In: Tonry M and Morris N (eds) Crime and Justice: A Review of Research, vol. 12. Chicago: University of Chicago Press, 277-318.

Bässmann J (2011) Vehicle theft reduction in Germany: The long-term effectiveness of electronic immobilisation. European Journal of Criminal Policy Research 17: 221-246.

Behavioural Insights Team (2014) Reducing Mobile Phone Theft and Improving Security. London: Home Office.

Brand S and Price R (2000) The Economic and Social Costs of Crime. Home Office Research Study 217. London: Home Office. 
Brown R (2015) Reviewing the effectiveness of electronic immobilisation: Evidence from four countries, Security Journal 28(4): 329-351.

Brown R (2016) Vehicle crime prevention and the co-evolutionary arms race: Recent offender countermoves using immobiliser bypass technology, Security Journal doi:10.1057/s41284016-0001-1

Churchill D (2015) The spectacle of security: Lock-picking competitions and the security industry in mid-Victorian Britain. History Workshop Journal 80: 52-74.

Churchill D (2016) Security and visions of the criminal: Technology, professional criminality and social change in Victorian and Edwardian Britain, British Journal of Criminology 56: 857-876.

Clarke RV (1999) Hot Products: Understanding, Anticipating and Reducing Demand for Stolen Goods. Police Research Series Paper 112. London: Home Office.

Clarke RV (2012) Opportunity makes the thief. Really? And so what? Crime Science 1(2): 1-9.

Clarke RV (2015) Criminology and the fundamental attribution error. Stockholm Criminology Symposium 2015. Stockholm, Sweden, URL (accessed 2 August 2016): http://www.criminologysymposium.com/symposium/event-information/video-clips/2015.html ('Prize winners lecture', minutes 11 to 45$)$.

Clarke RV (2016) Criminology and the fundamental attribution error The Criminologist 41(3): $1-7$.

Clarke RV (2018) The theory and practice of situational crime prevention. Oxford Research Encyclopedia of Criminology. Oxford: Oxford University Press. DOI: 10.1093/acrefore/9780190264079.013.327 (online January 2018).

Clarke RV and Bowers K (2017) Seven misconceptions of situational crime prevention. In: Tilley $\mathrm{N}$ and Sidebottom A (eds) Handbook of Crime Prevention and Community Safety, 2nd edition. Abingdon: Routledge, 109-142.

Clarke RV and Harris PM (1992) Auto theft and its prevention. Crime and Justice 16: 1-54.

Cornish DB and Clarke RV (1987) Understanding crime displacement: An application of rational choice theory. Criminology 25(4): 933-948.

Cox K (2008) The application of crime science to medication errors. British Journal of Nursing 17(14): 924-927.

Davis M (1990) City of Quartz. London: Verso.

Eck JE (1993) The threat of crime displacement. Criminal Justice Abstracts 25: 527-546.

The Economist (2019) Hold on a millisecond: British ethicists are challenging justice by algorithm, 8 August.

Ekblom P (1999) Can we make crime prevention adaptive by learning from other evolutionary struggles? Studies on Crime and Crime Prevention, 8: 27-51.

Ekblom P (2005) Designing products against crime. In: Tilley N (ed.) Handbook of Crime Prevention and Community Safety. Cullompton: Willan.

Ekblom P (2017) Crime prevention through product design. In: Tilley N and Sidebottom A (eds) Handbook of Crime Prevention and Community Safety, 2nd edn. London: Routledge, 207-233.

Farrell G, Tseloni A and Tilley N (2011) The effectiveness of car security devices and their role in the crime drop. Criminology and Criminal Justice 11(1): 21-35.

Farrell G, Tseloni A, Mailley J and Tilley N (2011) The crime drop and the security hypothesis. Journal of Research in Crime and Delinquency 48(2): 147-175.

Felson M and Clarke RV (1995) Routine precautions, criminology, and crime prevention. In: Barlow HD and Decker SH (eds) Criminology and Public Policy: Putting Theory to Work. Philadelphia, PA: Temple University Press, 106-120. 
Felson M and Clarke RV (1997) The ethics of situational crime prevention. In: Newman G, Clarke RV and Shoham SG (eds) Rational Choice and Situational Crime Prevention. Aldershot: Ashgate.

Fujita S and Maxfield M (2012) Security and the drop in car theft in the United States. In: Van Dijk JJM, Tseloni A and Farrell G (eds) The International Crime Drop: New Directions in Research. London: Palgrave Macmillan.

Gill M (2014) Exploring some contradictions of modern-day security. In: Gill M (ed.) The Handbook of Security, Second Edition. Basingstoke: Palgrave Macmillan.

Grüne-Yanoff T (2012) Old wine in new casks: Libertarian paternalism still violates liberal principles. Social Choice and Welfare 38: 635-645.

Guerette R and Bowers K (2009) Assessing the extent of crime displacement and diffusion of benefits: A review of situational crime prevention evaluations. Criminology 47(4): 1331-1368.

Hesseling R (1994) Displacement: A review of the empirical literature. In: Clarke RV (ed.) Crime Prevention Studies, vol. 3. Monsey, NY: Criminal Justice Press.

Home Office (2005) The Economic and Social Costs of Crime against Individuals and Households 2003/04. Home Office Online Report 30/05. London: Home Office.

Ignatans D and Pease K (2016) The global crime drop and changes in the distribution of victimisation. Crime Science 5(11): 1-6.

Koumpis C, Farrell G, May A, Mailley J, Maguire M and Sdralia V (2007) To err is human, to design-out divine: Reducing human error as a cause of cyber-security breaches. Supporting document for DTI Human Factors Working Group, Cyber Security Knowledge Transfer Network, White Paper on Human Vulnerabilities and Cyber Security. Vodera Ltd \& Loughborough University.

Kurland J, Pires SF, McFann SC and Moreto WD (2017) Wildlife crime: A conceptual integration, literature review, and methodological critique. Crime Science 6(4): 1-15.

Light R, Nee C and Ingham H (1993) Car Theft: The Offender's Perspective. Home Office Research Study 130. London: HMSO.

Menon C (2016) Is your car the most stolen model in England and Wales? The Guardian, 25 June. URL (accessed 2 June 2020): https://www.theguardian.com/money/2016/jun/25/hi-techthieves-keyless-car-crime-electronic-security.

Moskvitch K (2014) The road design tricks that make us drive safer. BBC Future, 17 April. URL (accessed 2 June 2020): http://www.bbc.com/future/story/20140417-road-designs-that-trickour-minds.

Newman G (2004) Car safety and car security: An historical comparison. In: Maxfield MG and Clarke RV (eds) Understanding and Preventing Car Theft. Crime Prevention Studies, Vol. 17. Monsey, NY: Criminal Justice Press, 217-248.

Norman DA (2002) The Design of Everyday Things. London: Basic Books.

Neocleous M (2007) Security, commodity, fetishism. Critique 35(3): 339-355.

ONS (Office for National Statistics) (2016) Crime in England and Wales: Year Ending Mar 2016. Statistical Bulletin, 21 July 2016.

Painter K and Farrington D (1997) The crime reducing effect of improved street lighting. In: Clarke R (ed.) Situational Crime Prevention: Successful Case Studies. New York: Harrow and Heston, 209-226.

Pease K and Laycock G (2012) Ron and the Schiphol fly. In: Tilley N and Farrell G (eds) The Reasoning Criminologist: Essays in Honour of Ronald V Clarke. New York: Routledge.

Petrossian G, Weis JS and Pires SF (2015) Factors affect crab and lobster species subject to IUU fishing. Ocean \& Coastal Management 106: 29-34. URL (accessed 2 June 2020): http:// dx.doi.org/10.1016/j.ocecoaman.2015.01.014. 
Poyner B and Webb B (1997) Reducing theft from shopping bags in city center markets. In: Clarke R (ed.) Situational Crime Prevention: Successful Case Studies. New York: Harrow and Heston, 83-89.

Sidebottom A (2013) On the application of CRAVED to livestock theft in Malawi. International Journal of Comparative and Applied Criminal Justice 37(3): 195-212.

Skudder H, Brunton-Smith I, McInnes A, Druckman A and Cole J (2016) Does cutting crime also cut carbon? Presentation to the International Symposium on Environmental Criminology and Crime Analysis, Muenster, Germany, 20-23 June.

Smith MJ and Cornish DB (2012) Secure and Tranquil Travel: Preventing Crime and Disorder on Public Transport. New York: Routledge.

Spencer E (1992) Car Crime and Young People on a Sunderland Housing Estate. Crime Prevention Unit Paper 40. London: Home Office.

Thaler RH and Sunstein CR (2008) Nudge: Improving Decisions about Health, Wealth, and Happiness. New Haven, CT: Yale University Press.

Thomson I (2016) If you use 'smart' Bluetooth locks you're asking to be burgled. The Register, 0 August. URL (accessed 2 June 2020): http://www.theregister.co.uk/2016/08/08/using_a smart_bluetooth_lock_to_protect_your_valuables_youre_an_idiot/.

Tilley N, Farrell G and Clarke R (2015) Target suitability and the crime drop. In: Andresen M and Farrell G (eds) The Criminal Act. London. Routledge.

Tobin D (2014) Six ways thieves can break into a car and how to prevent it. The Sunday Times, 3 November. URL (accessed 2 June 2020): http://www.driving.co.uk/car-clinic/six-waysthieves-can-break-into-a-car-and-how-to-prevent-it/.

Tseloni A, Mailley J, Farrell G and Tilley N (2010) Exploring the international decline in crime rates. European Journal of Criminology 7(5): 375-394.

Tseloni A, Farrell G, Thompson R, Evans E and Tilley N (2017) Domestic burglary drop and the security hypothesis. Crime Science 6(3): 1-16.

Van Dijk J, Van Kesteren J and Smit P (2007) Criminal Victimization in International Perspective: Key Findings from the 2004-2005 ICVS and EU ICS. The Hague: Boom Legal Publishers.

Van Ours JC and Vollaard B (2016) The engine immobiliser: A non-starter for car thieves. Economic Journal 126(593): 1264-1291.

Viscusi WK and Zeckhauser RJ (2003) Sacrificing civil liberties to reduce terrorism risks. Journal of Risk and Uncertainty 26(2-3): 99-120.

Wolpin S (2016) 5 best smart locks for your home. Techlicious (updated 12 March 2019). URL (accessed 2 June 2020): http://www.techlicious.com/guide/5-futuristic-smart-locks-for-yourhome/.

Wortley R (2010) Critiques of situational crime prevention. In: Fisher B and Lab S (eds) Encyclopedia of Victimology and Crime Prevention. Thousand Oaks, CA: Sage.

Wortley R (2017) Situational precipitators of crime. In: Wortley R and Townsley M (eds) Environmental Criminology and Crime Analysis, 2nd edn. Abingdon: Routledge.

Zedner L (2003) Too much security? International Journal of the Sociology of Law 31: 155-184. 